\title{
LAKÓTELEPEK ESZTÉTIKAI ÉRTÉKELÉSÉNEK KÍSÉRLETE SZEGEDI MINTATERÜLETEK ALAPJÁN
}

\author{
KARANCSI ZOLTÁN - HORNYÁK SÁNDOR - SZALMA ELEMÉR \\ - KOROM ANNAMÁRIA - OLÁH FERENC - HORVÁTH GERGELY \\ AN ATTEMPT AT THE AESTHETIC EVALUATION OF HOUSING ESTATES \\ BASED ON SZEGED SAMPLE AREAS
}

\begin{abstract}
The aesthetics of landscapes and the environment has not received considerable research attention. The main reason for this is that aesthetic evaluation contains too many subjective elements, which is not always compatible with the cold rationalism of researchers. Despite this, researchers regularly comment on the aesthetics of urban environments. This is not accidental. There is a connection between the aesthetics of phenomena and the decision-making with regard to them. The aesthetic appearance of an area affects millions of decisions regarding investments, tourism destinations, or the choice of dwelling-place.

In Hungary, around one third of the urban population is living in housing estates; this environment is an everyday reality for most of the urban population. The housing estates were built during the communist era and received major criticism almost instantly in both sociology and architecture. In recent decades both the Hungarian state and the local government of Szeged have made significant investments aimed at increasing the quality of the housing estates' environment.

For determining the aesthetics of housing areas and their environment, we improved our earlier-developed method, which was used for evaluating single downtown buildings. The improved method was tested in three different sample housing areas. For the evaluation of architecturally homogeneous, newly-constructed or refurbished buildings, we have introduced the concept of the visual unit, which incorporates multiple buildings and their surroundings. This solution speeds up the evaluation process, and it can also be used to score individual buildings, if necessary. We also examined visual conflicts which affect the aesthetics of the area and can reduce the value of the visual condition. The key result of our research is the thematic mapping of three categories, including the aesthetically valuable, and therefore attractive areas, which can be distinguished from the aesthetically problematic, and therefore repulsive areas, and from the areas which can be (and should be) improved aesthetically.
\end{abstract}

Keywords: environment aesthetics, visual conflict, housing estate, city development

\section{Bevezetés}

A minket körülvevő szűkebb vagy tágabb környezet látványát tájképként vagy településképként érzékeljük. Minden esetben a látványon keresztül kapjuk az elsố információt környezetünkről. A környezetesztétika jelentőségét éppen az adja, hogy a látvány hatással van az emberi pszichikumra, a szép környezet inspirál, az elhanyagolt, pusztuló környezet viszont lehangol. A látvány alapján képesek vagyunk következtetések levonására a környezet állapotáról, az épületek koráról, de akár az ott élő emberek társadalmi helyzetéról is (BudAi A. 2004, KARANCSi Z. et al. 2012). Abban, hogy a táj- és környezetesztétikai kutatásoknak mégis ilyen mostoha a helyzete, jelentős szerepet játszik az a tény, hogy túl sok benne a szubjektív elem. Az elkerülhetetlen szubjektivitás csökkentése érdekében szükség lenne olyan objektív mérőszámokon alapuló értékelő rendszerre, amely esztétikai alapon pontszámok segítségével minősíti környezetünket.

Városesztétikai kutatásainkat vizuális konfliktusok, majd egy szegedi belvárosi utca vizuális megjelenésének értékelésével kezdtük (KARANCSI Z. et al. 2013, 2017), ebben a ta- 
nulmányban pedig a lakótelepek vizuális értékelésére teszünk kísérletet. Dolgozatunkban a lakótelep kifejezésen a második világháború után, főként iparosított technológiával (de kisebb részben más technikával is), tömeges mennyiségben eloállított lakófunkciójú nagyvárosias épületek által uralt városi területeket értjük. Vizsgálatainknak a korábbi korszakokban, nem iparosított technikával épült telepszerú beépítések (ONCSA-telepek, cselédsorok, munkáslakások stb.) nem képezték tárgyát.

\section{Elméleti háttér}

A lakáshiány enyhítésére a múlt század második felében az ország minden részében felhúzott lakótelepek markáns látványelemként, meghatározó súllyal vannak jelen a magyar városképben. Magyarországon 772000 lakótelepi lakás van, ebből durván félmillió ún. „panellakás” (KSH 2013). Magyarországon az 1990-es éveket megelőzóen is voltak a lakótelepek leromlására utaló jelek, ám ezek a rendszerváltozás okozta szociális sokk következtében fenyegető veszéllyé váltak. A piaci viszonyok kialakulását számos helyen a lakótelep látható leromlása kísérte, ezek közül néhány - mint pl. a székesfehérvári Rádió utcai, a budapesti Havanna lakótelepi, vagy a miskolci Avas lakótelepi - a szélesebb közvélemény előtt is ismerté vált. Ugyanakkor a telepek egészének teljes leépülését minden lakótelepen sikerült megelőzni.

A lakótelepek esztétikájának kérdése soha nem állt a településformáról szóló viták célkeresztjében, ugyanakkor jellemző, hogy a kutatók a téma lezárásakor vagy felvezetésekor a saját objektív eredményeiken túlmutató ítéletet kívántak mondani a lakótelepi környezet egészéről. A lakótelepeket két oldalról is érte kritika, küllemüket illetôen. Elsőként az építész és várostervező szakma részéről érkezett kedvezőtlen, a lakosság szélesebb rétegeihez is eljutó visszajelzés: kezdetben még csak a lakótelepek elkülönülését, a várostesten belül szinte „,idegen testként” történő megjelenését kritizálták (JACOBS, J. 1961), majd az 1970-es évek lakótelepeit már monoton és sivár megjelenésük miatt is elmarasztalták. A rendszerváltozás előtt az 1970-es évek lakótelepeinek esetéből tanulva, elsősorban a közép- és kelet-európai (NDK-beli, szovjet) tapasztalatokra építve indult el egy olyan kezdeményezés, amely fóként építészeti szempontokra összpontosítva próbálta esztétikailag is változatosabbá tenni a paneles építési technológiát, aminek következtében az 1980-as évektől már tetszetôsebb, változatosabb megjelenésû lakótelepekkel is találkozhattunk. Ugyanakkor a lakótelepek kérdésével foglalkozó írásokban kevés nyoma volt a lakótelep-építés gyors nyugati hanyatlásának. Ott ugyanis elóbb a magasházak, majd a '80-as évek elején a rossz tapasztalatok miatt a lakótelepek építésével is jobbára felhagytak. Ezen országokban a lakótelepek a politika számára szociálpolitikai eszközökkel nem javítható etnikai gettókká váltak, ahol gyakran a várostervezés legdrasztikusabb eszközéhez, a tömeges bontáshoz nyúltak (RAINWATER, L. 1970, RAMROTH, W. 2007). A lakótelepekre ezért Nyugat-Európában egyre inkább rossz életminőséget előidéző lakóhelyformaként tekintettek, amely versenyképtelen a szuburbán ,zöld” városokkal szemben.

A lakótelepek vizuális állapotával elsősorban az építészet foglalkozott, a lakótelepek társadalmi hatásait, a terek gazdátlanságát és az uniformizált küllemet (JACOBS, J. 1961, Coleman, A. M. 1985), illetve a saját tér védelmének lehetetlenségét (NEWMANN, O. 1970) kifogásolva. NEwMANN joggal mutat rá arra, hogy az általa kritizált lakótelepeken a személyes tér a lakásba szorul vissza és a házak körül nem alakul ki egy olyan „félprivát” zóna, amelyet az ott lakók sajátjukként kezelhetnének. A helytakarékosság és költséghatékonyság miatt nincsenek „kiülős” részek, előkertek, ezért az ott lakók a lakásukból kilépve már a lépcsőházban az intim zónán kívül találják magukat. Ezt még fokozza, hogy 
a lépcsôházi hangoskodás, a szagok, az utcai ribillió révén a nyilvános tér benyomul az emberek lakásába, a lakóknak pedig semmi esélyük sincs ezen folyamat ellen bármit is tenni, ami a személyes terüket megvédené. Magyarországon hasonló gondolatokat PREISICH G. (1984) fejtett ki és hívta fel a figyelmet a „monofunkcionális életterek” nyomasztó és sivár mivoltára. Napjainkban a Budapesti Múszaki Egyetemen folynak a hazai lakótelepek vizuális állapotát vizsgáló építészeti szempontú kutatások (BENKŐ, M. 2012, BENKŐ M.-BALLA R. 2016).

A lakótelepekkel kapcsolatban az 1960-as évek végétől kezdve kerültek elő a szociológia nézőpontjából származó kritikák (KONRÁD GY.-SzELÉNYI I. 1969). A társadalomtudomány a lakótelepek esztétikai lezüllését egyszerre tekintette a rossz társadalmi környezet okának, következményének és jelzőjének is. Jelentősek voltak a szociológiai és esztétikai kifogások, többek között a telepek tömeges megjelenését („,betondzsungel”), monotonitását és ezáltal embertelenségét emelték ki (GYÖRGY P.-DuRKÓ Zs. 1993, RÁCZ J.-HOYER M. 1995, VON DER HAGEN-DEMSZKY A. 2005). Egyes kutatók egészen elítélően szóltak (egyes) lakótelepek környezetéről: „silány”, „lakólyuk”, „monoton, egyhangúan szürke és sivár” (IvÁN L. 1996), ,igénytelen” és „embertelen” (KovÁcs Z.-DougLAS, M. 1996). Mások (KovÁcs Z.-Douglas, M. 1996; EGEDY T. 2005) a lakótelepek múszaki, lakáspiaci és társadalmi problémáit kiteljesítő vizuális problémákat „lakótelep-szindróma" néven foglalták össze.

Áttételesen ugyan, de a szociológia és a szociálgeográfia is fontos információként tekint a lakótelepek vizuális állapotára. A szociológia a lakókörnyezet vizuális konfliktusait a szociális problémák azonosítására alkalmas indikátorként használta fel (DEKKER, K. 2011). Ilyen eszközzel az egykori keleti tömb lakótelepeit kutatók esetében is találkozunk (SARGiSiAn, T. 2013). (Tanulmányunkban vizuális probléma vagy vizuális konfliktus kifejezéseken egyrészt a természetesnek mondható elhasználódás és múszaki avulás azon jeleit értjük, amelyek a tetszetősség és a használhatóság tekintetében az átlagember számára is érezhetôen csökkentik szűkebb vagy tágabb környezetük látványértékét, másrészt a szándékos rongálás és a nem rendeltetésszerű használat látványban is megnyilvánuló következményeit.)

A lakótelepeknek az építészeti hiányosságaikon túli diszfunkcionális elemeit és esztétikai problémáit a szerzők több különböző okra vezetik vissza. Ezen érvelések mindegyike a társadalom és a környezet egymásra hatásaként értékeli azokat. Markáns álláspontot képvisel EGEDY T. (2000, 2005), szerinte a lakókörnyezet határozza meg az életminőséget. Ez a piaci viszonyok között olyan alapot jelent, amely meghatározza a társadalmi környezet minőségét. Ugyanakkor a társadalmi környezet bizonyos mértékben vissza is hat az építettre. Különösen igaz ez az (alsó) középosztály által lakott helyekre, például a lakótelepekre, ahol a polgároknak csak kevés lehetőségük van kitérni a környezet negatív jelenségei elől, mert alacsonyabb jövedelmük miatt nem képesek saját kis ,rezervátumok” létrehozására. EGEDY szerint az épületek korszerúsítése mellett a legfontosabb feladat a telepek környezetének frissítése és az épületek küllemének javítása.

A lakótelepeket érintő jogos kritikák ellenére a hagyományos, összefüggő utcafrontokat alkotó beépítéssel szemben az elkülönülő blokkházak a köztük lévő kiterjedt szabad terekkel lehetőséget is teremtettek a modernista urbanisztika számára, mégpedig hogy parkosítással az önmagukban sivár lakóépületek szinte „ússzanak a zöldben”. Összességében ugyanis a lakótelepeken lényegesen jobb zöldfelület-ellátottsági mutatók alakultak ki, mint a hagyományos lakóterületek többségén (PAP Á. 2017).

Részben a kritikák hatására, részben a kialakult társadalmi feszültségek kezelésére a rendszerváltozás után többnyire a lakóközösségek kezdeményezésére, helyenként állami vagy önkormányzati beavatkozással, máshol a magántulajdonná vált lakások tulajdono- 
sainak saját elhatározásából beindultak a lakótelepek felújítását célzó programok. Ezek javítottak a helyzeten, de a felmerült problémákat teljes mértékben nyilván nem voltak képesek orvosolni. Magyarországon már 1997-ben tettek kísérletet német hitelből finanszírozott panelfelújításra, de nagyobb léptékben 2000-ben a Széchenyi Tervben született meg az első országos stratégia a panelházak energiatakarékos felújítására és átalakítására, ez volt a Panelprogram, amit 2005-ben Panel Plusz néven újra meghirdettek. 2008 végéig országosan 190000 panellakás újult meg. 2008-ban a Panel I., majd 2009-ben a Panel II. néven mentek tovább a programok, amelyekben folyamatosan bővült a támogatások köre (napkollektorokra, napelemekre, majd komplex felújításokra is lehetett pályázni). A programot már a kezdetektől az ún. egyharmados szabály jellemezte, miszerint a költségek egyharmadát a Panelprogram, egyharmadát a helyi önkormányzat és egyharmadát a lakóközösség állja. Ez 2009-ben úgy módosult, hogy az állam a szén-dioxid-kvótából fedezte a Panel II. programot, így a szigorú minőségi kritériumok teljesülése esetén az állami támogatás aránya már elérhette akár a 60\%-ot is. 2014-tôl indult el a Panel III. program, finanszírozása a kvóták mellett kiegészült EU-támogatással, a 2014-es költségvetési ciklusban már a Környezeti és Energiahatékonysági Operatív Programból (KEHOP) lehetett rá támogatást nyerni (SZABó B.-BENE M. 2019).

\section{A szegedi lakótelepek története}

Szegeden is a korszerútlen otthonokban élő tömegek gyors lakáshoz juttatásának követelménye hozta létre a városi lakótelepeket, amelyek az 1960-as évektől kezdődóen szinte folyamatosan épültek az 1990-es évek végéig. A gyorsaság iparosított múszaki megoldásokat igényelt, a technikai fejlődés pedig lehetővé tette a gyors technológiák bevezetését. Ezen technológia kivitelezési, szervezési kötöttségei elérhetővé tették a modernista urbanisztikának a hagyományos városszerkezet béklyóitól szabadulni akaró törekvéseit. A kiépülő lakótelepek tervezésekor szakítottak az évszázados települési hagyományokkal, az új rendben a korábbi fogalmak - utcák, utcaképek - értelmezhetetlenné váltak, helyüket a különálló ,,pontházak”, illetve „,szalagházak” közötti ,áramló tér” vette át.

Ennek szellemében az 1960-as évek közepétől meg is kezdődött a régi Tarján, valamint az ekkor Odesszának elnevezett új városrész beépítése, akkor még téglablokkos építési technológiával. Ennek előnye volt, hogy a blokkos kivitelezési eljárás valamivel több szabadságot adott a tömegformálásnak, mint a késóbb, az 1970-es évek kezdetétôl kizárólagossá vált paneles építési technikát alkalmazó házgyári technológia, amely viszont gyorsabb és tömegesebb lakástermelést tett lehetôvé. Ekkortól épült be teljesen a mai Tarján városrész és az ún. Északi városrész, majd az 1980-as években született meg a kiterjedt Újrókus és Makkosház. Fontos megjegyezni, hogy Szegeden a lakótelepi városrészek - sok más magyarországi lakóteleppel ellentétben - szerkezetileg illeszkedtek a város addigi szövetéhez. Az említett Makkosház és Újrókus új lakótelepeinek építésével fejeződött be Szeged harmadik körútjának a létrehozása, illetve a sugárutak kiépülése is (1. ábra) (Tóth K.-KeSERÚ I. 2001, BlazOVICH L. 2007).

Városesztétikai szempontból feltétlenül ki kell emelni, hogy az első szegedi lakótelepek - Tarján és Odessza - tervezőit még a kor urbanisztikájának pozitivista lelkesedése hatotta át, ezért e városrészek egységes, máig figyelemre méltó városépítészeti koncepció mentén valósultak meg. Ilyen volt az egy főre jutó magas zöldfelület-arány elve, amelynek köszönhetően a magasházas beépítésû́ területek szomszédságában rendre nagy kiterjedésú zöldfelületeket alakítottak ki. Szintén szerepet kapott az elválasztott forgalom elve, amely a lakótelepi forgalmat viszonylag szúk csatornákba koncentrálta, a „szupertömb” 


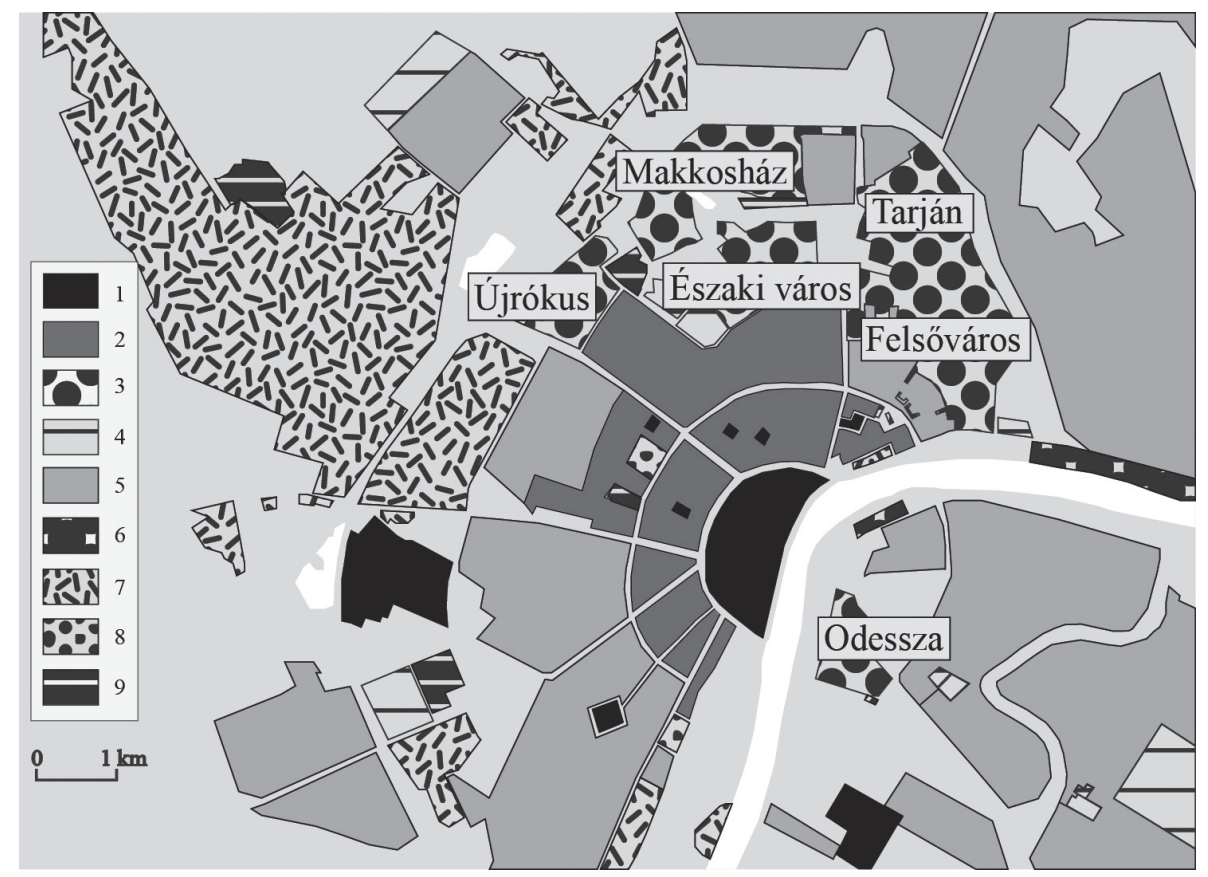

1. ábra A szegedi lakótelepek elhelyezkedése (szerk. KARANCSI Z.)

Jelmagyarázat: 1 - turistaövezet; 2 - régi lakóöv; 3 - lakótelep; 4 - lakópark; 5 - családi és társasházak; 6 - üdülőövezet; 7 - iparterület; 8 - pályaudvar; 9 - bevásárlóközpont.

Figure 1. Location of housing estates in Szeged (ed. by KARANCSI, Z.)

Legend: 1 - Tourism zone; 2 - old residential area; 3 - housing estates; 4 - living estates; 5 - family and apartment houses; 6 - holiday zone; 7 - industrial area; 8 - railway stations; 9 -shopping centres.

belsejében pedig nagy kiterjedésú, átmenő forgalomtól mentesített zöldfelületeket hozott létre. A lakóépületek falanszterjellegét igényes kertészeti megoldásokkal, előremutató középületekkel, korszerű közlekedési hálózattal, rekreációs létesítményekkel próbálták ellensúlyozni. Emellett a szegedi oldal lakótelepi tömbjeinek monotonitását rendre vízfelületek - Zápor-tó, Vér-tó, Búvár-tó - is megtörik. Hasonló szerepet játszanak a lakótelepek szomszédságában elhelyezkedő jelentősebb zöldfelületek, ezek közé számíthatjuk Szeged „láthatatlan körútját”, az ún. Körtöltést, az erdősült tiszai ártér egy szakaszát, illetve az Északi városrész szomszédságában álló ún. Kiserdőt is. A szegediek számára a budapesti Városligetéhez hasonló jelentőségű és szerepkörű az Odessza lakótelep melletti Liget. Ugyanakkor olyan - IvÁN L. (1996) által hulladékterületnek nevezett - zöldfelületek is találhatók Szegeden, amelyek közvetlenül a lakótelepek mellett helyezkednek el, de a városlakók számára semmiféle szolgáltatást nem kínálnak. Ide az Újrókus és a körtöltés közé szorult nagy kiterjedésű bozótosokat, a korábban felszámolt és évtizedek óta elhagyatott Gyevi temető telkét, illetve a Franciahögy területét sorolhatjuk.

A lakótelepek korábban már említett állapotromlása miatt szükségessé vált felújításuk. Az épületek rekonstrukciója során a technikai megújítás mellett fontos cél volt az építészeti arculat sivárságának enyhítése is. Az épületek ,felöltöztetésével” építészeti elemekkel csinálnak házat a „dobozból”. Ennek eredményeként a napjainkban megújított zöldterületek és az építészetileg felújított házak a korábbinál kellemesebb, impulzívabb lakókörnyezetet biztosítanak, amelyben erőteljesebben érvényre juthatnak e sajátos városépítészeti forma tényleges előnyei, ugyanakkor csökkennek hátrányai (2.ábra). 


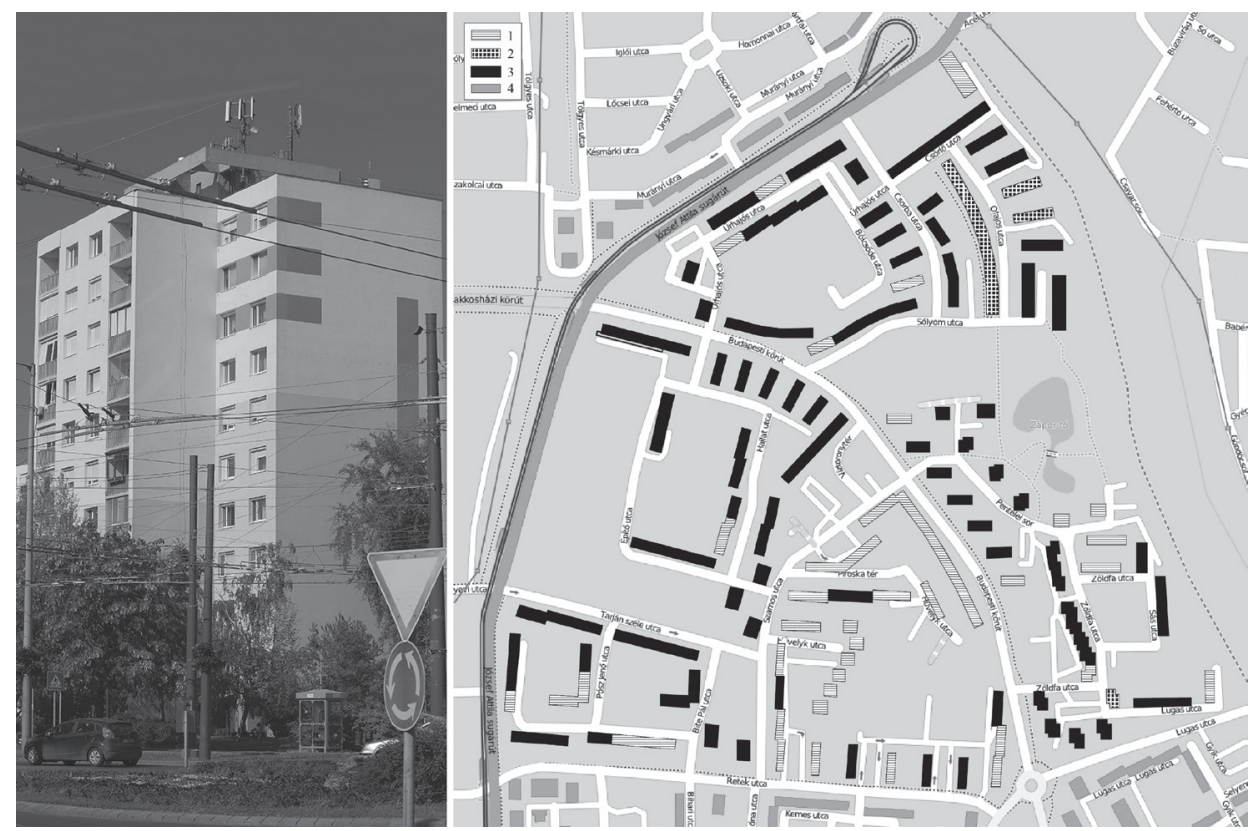

2. a-b) ábra A Panelprogram által megújult tarjáni tízemeletes különálló épület (a) (fotó KARANCsi Z.) és a tarjáni panelek (lakóépületek) felújításának foka (b) (szerk. HoRNYÁK S.)

Jelmagyarázat: 1 - homlokzati felújítás nélküli épület; 2 - részleges felújításon (hőszigetelés, festés) átesett épület; 3 - komplex felújításon (nyílászárócsere, hőszigetelés, festés) átesett épület; 4 - a vizsgált területen kívüli panelépület. Figure $2 a-b) 10$ storey housing estate building, renewed during the housing estate renovation programme

(so called "panel program") (a) (photo: KARANCSI, Z.) and the grade of renovation of buildings in Tarján, Szeged, Hungary (b) (ed. by HORNYÁK, S.) Legend: 1 - building without renovation of facade;

2 - building with partial renovation (insulation, colouring); 3 - building with complex renovation (windows, insulation, colouring); 4 - housing estate buildings outside the investigated area

\section{Módszerek, mintaterületek}

Az elmúlt század közepén történtek az első kísérletek a szépség és tetszetősség számszerúsítésére. Ezen törekvésnek a magyarországi építészeti irodalomban is maradtak fellelhető nyomai (JózSEF D. 1986). Egy korábbi tanulmányunkban (KARANCSI Z. et al. 2017) már bemutattunk egy utcakép-értékelő módszert, amellyel épített környezetünk látványát minősíttettük. A több szempontot figyelembe vevó értékelés egy adott utca különböző épületeinek látványát értékelte, majd a kapott pontok átlagával az utcakép látványa is kifejezhetővé vált, amit egyfajta „településesztétikai indexnek” nevezhetnénk. Ám mivel környezetünk látványa meghatározza viszonyunkat környezetünkhöz, vagyis pozitív értékelésnél azt élhetőbbnek ítéljük, ezért tanulmányunkban a kapott értékszámokra a Vizuális Élhetôségi Index (VÉI) fogalmát használtuk.

Ezt a minősítő rendszert a lakótelepi környezet értékeléséhez átalakítottuk. Ebben a tanulmányunkban ezt fogjuk bemutatni. Az utcakép látványértékének kifejezésére kialakított korábbi módszer más utcaképek, míg a jelenleg ismertetett módszer más lakótelepeken elvégzett hasonló vizsgálatok eredményeinek, azok vizuális megjelenésének értékszámokkal kifejezett összehasonlítását teszi lehetővé. Az új értékelő lap kialakítása során úgy ítéltük meg, hogy a lakóépületek állapotértékelési kategóriái közül mindhármat megtartjuk, annak ellenére, hogy a legrosszabb (1-es) kategóriával eddig csak az egykori 
szovjet laktanyákhoz tartozó, elhagyott tiszti lakótelepeken találkoztunk, ami megfelel az EGEDY T.-féle (2005) „nem menthető” kategóriának.

Mivel a belvárosi palotákkal, bérházakkal ellentétben a többnyire jóval fiatalabb és sokkal egységesebb épületekből álló lakótelepek nem rendelkeznek turisztikai jelentőséggel, így ez nem is jelenik meg kiegészítő pontként az értékelésben. Ugyanakkora sajátos téralakítás - az elkülönülten álló épületblokkok közötti áramló tér, vagy a szalagházak között kialakított parkok - miatt a növényzet szerepe felértékelődött, ezért azt nemcsak hogy az alapértékek közé emeltük, hanem a gondozott, egészséges növényzet azonos súllyal szerepel az értékelésben, mint a jóval költségesebb és idôt állóbb homlokzatfelújítás. Az alapértékek közé kerültek a nem lakófunkcióval rendelkezó épületek (fútésközpont, trafóház stb.) is, amelyek leggyakrabban ugyan eltörpülnek a lakóépületek mellett, ennek ellenére - állapotuktól függően - akár jelentős hatást is gyakorolhatnak a látványra. Szintén ide tartoznak a közintézmények (pl. iskolák, boltok, bevásárlóközpontok) is, amelyek legfeljebb magasságukban törpülnek el a lakóépületek mellett, de alapterületük akár többszöröse is lehet azoknak. A kiegészítő értékek között nagyon fontos értéknövelő szerepet kapott a vízfelület, és látványértéket meghatározó szerepe lehet az utcaszobroknak, utcadíszeknek, vagy akár egy múvészi igénnyel elkészített utcai múvészi (street art) alkotásnak is. Az alap- és kiegészítő értékekre kapott pontszámokból vontunk le az esetlegesen megjelenő vizuális konfliktusok mértékének függvényében egy vagy két pontot.

Az értékelés során fontos szempont volt a szubjektivitás torzító hatásának minimalizálása, vagyis e vizsgálat keretében is a lehető legkisebb számú, mindössze három érték választását lehetôvé tevő minősítő rendszert alkalmaztuk. Az átalakított értéktáblázatban az alapértékek legrosszabb (1) és közepes (2) értékei tekinthetők akár vizuális konfliktusnak is (emiatt jelöltük kiemelten ezeket), de mivel egy külön táblázatba szedtük össze a látványt befolyásoló vizuális konfliktusokat (negatív pontszámokkal), ezért ettôl most eltekintettünk (1. táblázat). Csak azok a vizuális konfliktusok kerültek a táblázatba, amelyekkel a kutatási területünkön találkoztunk (3. ábra). Megjegyezzük, hogy más területekre alkalmazva a lista természetesen bővíthető.

Az értékelésre kiválasztott területek mindegyike a 20. század második felében állami nagyberuházás keretében ún. nagypaneles épületekkel beépített városi terület. Közös jellemzőjük, hogy a történelmi belvárostól nagyjából azonos távolságra helyezkednek el, és döntően lakófunkcióval, illetve az ahhoz közvetlenül kapcsolódó egyéb funkciókkal rendelkeznek. A területek egyikét sem jellemzi a lakótelepi átlagtól észrevehetően elütő társadalmi összetétel, népsűrűség vagy jövedelmi szint. A három mintaterület ugyanakkor ugyanazon építészeti és környezetalakítási törekvések háromféle módon történő megvalósulására lehet példa.

Vizsgálódásunkat egy tarjáni sorházzal lehatárolt utcakép értékelésével kezdtük (1. mintaterület), majd egy mellette lévő, épület- és parkrekonstrukción átesett rekreációs területen (Zápor-tó és környéke) folytattuk (2. mintaterület). Harmadik vizsgálati területnek egy nagyobb kiterjedésű térséget (Újrókus) választottunk, ahol egy forgalmas körútszakasz két oldalán álló, sorházakkal határolt parkok és felújított különálló panelépületek által körülvett és újjáélesztett parkosított vízfelület (Vér-tó) található, amely fontos rekreációs funkcióval rendelkezik.

Először házanként értékeltük az épületeket és közvetlen környezetüket. A látvány alapján szegedi kutatócsoportunk minden tagja (5 fő) egymástól függetlenül kitöltötte az értékelő táblázatot. Megállapítható, hogy a kapott eredmények között nem volt lényeges különbség (eltérés csak apróságokban, pl. egy fa korának megállapításában vagy kisebb esztétikai problémák észlelésében jelentkezett). Az utcakép látványának megítélésében ezért egységes vélemény alakult ki, így a módszer múködőképesnek bizonyult. Ugyanakkor kíváncsiak voltunk arra is, hogy egy homogén (azaz egy időben, azonos technológiával épült, nagyjából ugyanakkor felújított) építészeti egység esetén szükség van-e minden esetben épületenként 
A lakótelepek környezetesztétikai értékelése (szerk. KARANCSI Z.)

1. táblázat - Table 1

Evaluation of environmental aesthetics of housing estates (ed. by KARANCSI, Z.)

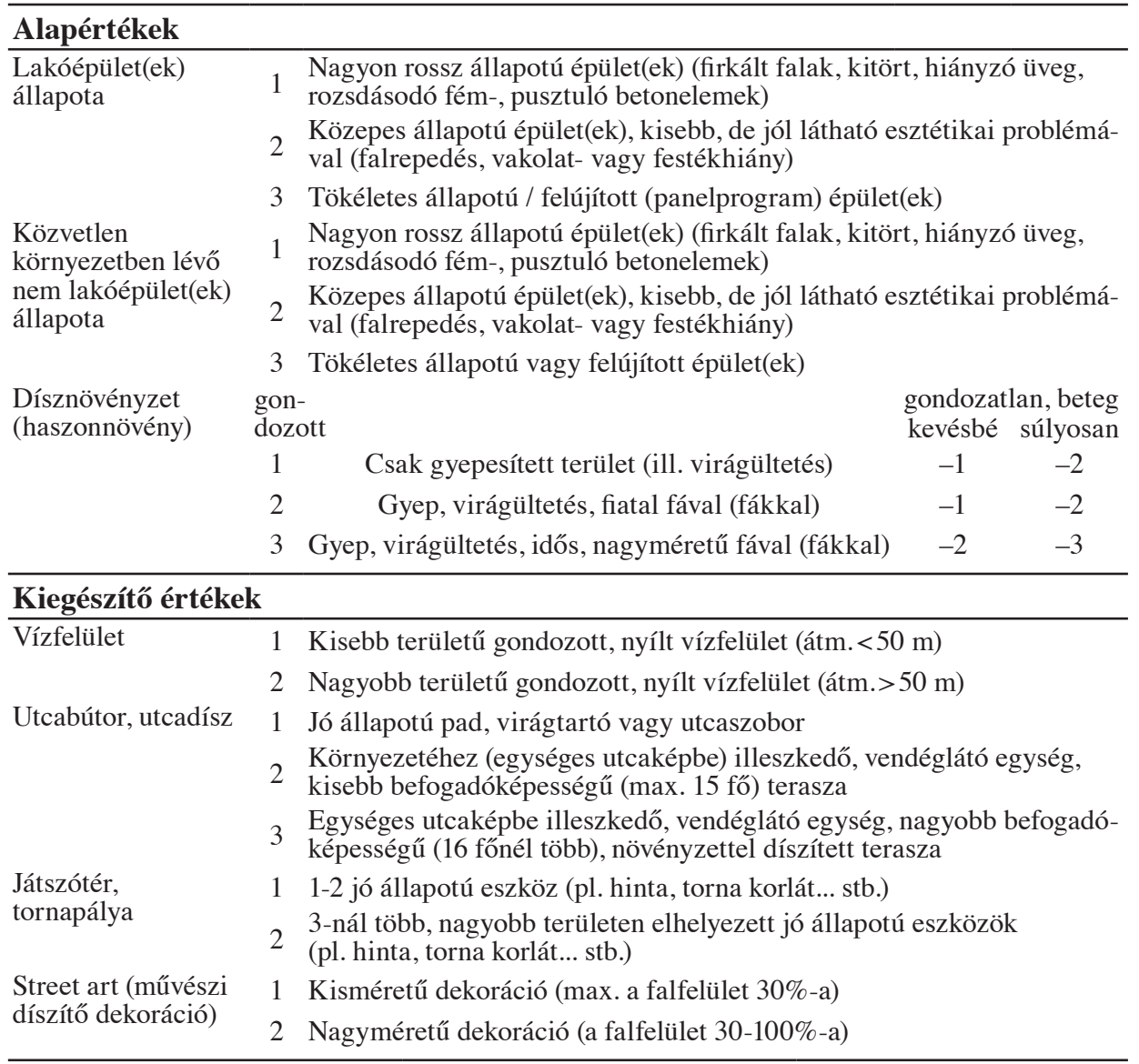

\section{Vizuális konfliktusok}

Elhanyagolt vízfelület

Kismértékú vizuális konfliktus Súlyos vizuális konfliktus

Gyomnövény

$-1$

$-2$

Penészes fal

$-1 \quad-2$

Falfirka (grafitti)

$-1 \quad-2$

Megrongált pad

$-1 \quad-2$

Piszok (por), szemét

$-1 \quad-2$

Töredezett járda

$-1 \quad-2$

Reklámhirdetés (reklámtakarás)

$-1 \quad-2$

Lég vezeték

$-1 \quad-2$

Forgalom (zaj)

$-1 \quad-2$

Szag (bűz)

$-1 \quad-2$

$-1 \quad-2$ 
értékelni, vagy pontosan ezen egységesség miatt - ahol a különbségeket csupán a helyileg megjelenő vizuális konfliktusok okozzák - elegendő-e a homogén utcarészekből nagyobb, ún. vizuális egységeket kialakítani, amelyek a szemünk által jól befogható (beazonosítható) épületekkel, növényekkel (fákkal, bokrokkal) lehatárolt téregységeknek tekinthetôk. Így leegyszerúsödik a feladat, hiszen a vizuális egységek közepén megállva, ott körbenézve statikus módon szemrevételezzük, majd pontozzuk a látványt. Igaz ugyan, hogy ezzel a módszerrel az egyes részletek nem minden esetben észlelhetők, de így valójában egy a látványról kialakuló esztétikai összbenyomás tükröződik az adott pontszámokban, érzékeltetve ebben azokat a vizuális konfliktusokat is, amelyek befolyásolják a látványt.
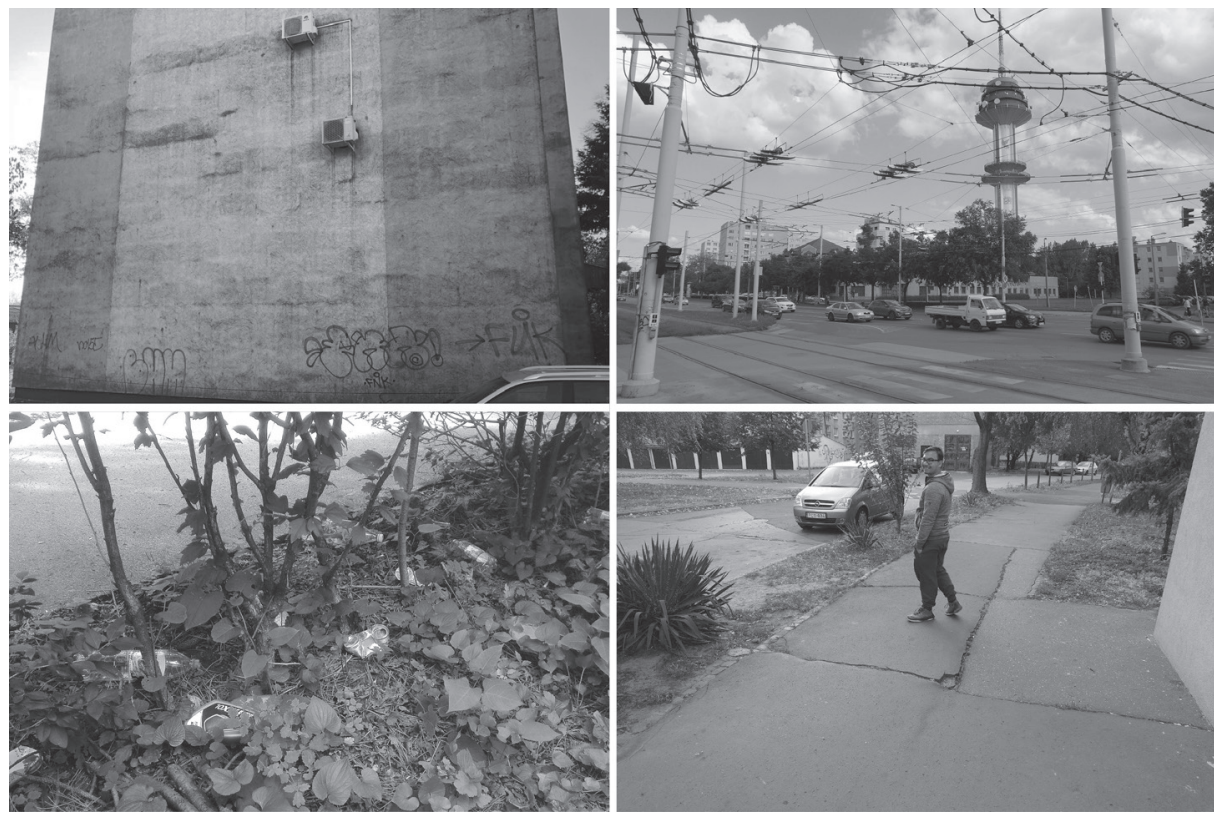

3. a-d) ábra Vizuális konfliktusok: a) penészes, összefirkált fal; b) légvezetékek, forgalom (zaj); c) szemét;

d) feltöredezett járda (fotó KARANCSI Z.)

Figure $3 a$-d) Visual conflicts: a) fusty, graffiti-covered wall; b) powerlines, traffic (noise); c) rubbish;

d) damaged sidewalk (photo KARANCSI, Z.)

\section{Eredmények}

\section{Az 1. mintaterület (Sólyom utca és környéke) környezetesztétikai értékelése}

Első vizsgálatunk során átalakított értékelő módszerünket egy tarjáni utcában teszteltük, amelynek egyik oldalán egymás mellé épített ötemeletes panel sorházak, illetve az utcára merőlegesen elhelyezkedő téglablokkos, ötemeletes sorházak, míg a másikon parkosított környezetben lévő közösségi épületek találhatók (4. ábra). Az utca kevéssé forgalmas, annál inkább a Budapesti körút, amelybe becsatlakozik.

Az értékelő táblázatok adatait megvizsgálva a kapott pontok tekintetében nagy különbségek nem tapasztalhatók, különösen ott nem, ahol egy időben épült, majd nagyjából ugyanakkor felújított - vagyis tulajdonképpen azonos állapotú - épületek találhatók (2 .táblázat); az eltéréseket leginkább a helyileg megjelenő vizuális problémák miatti pontle- 


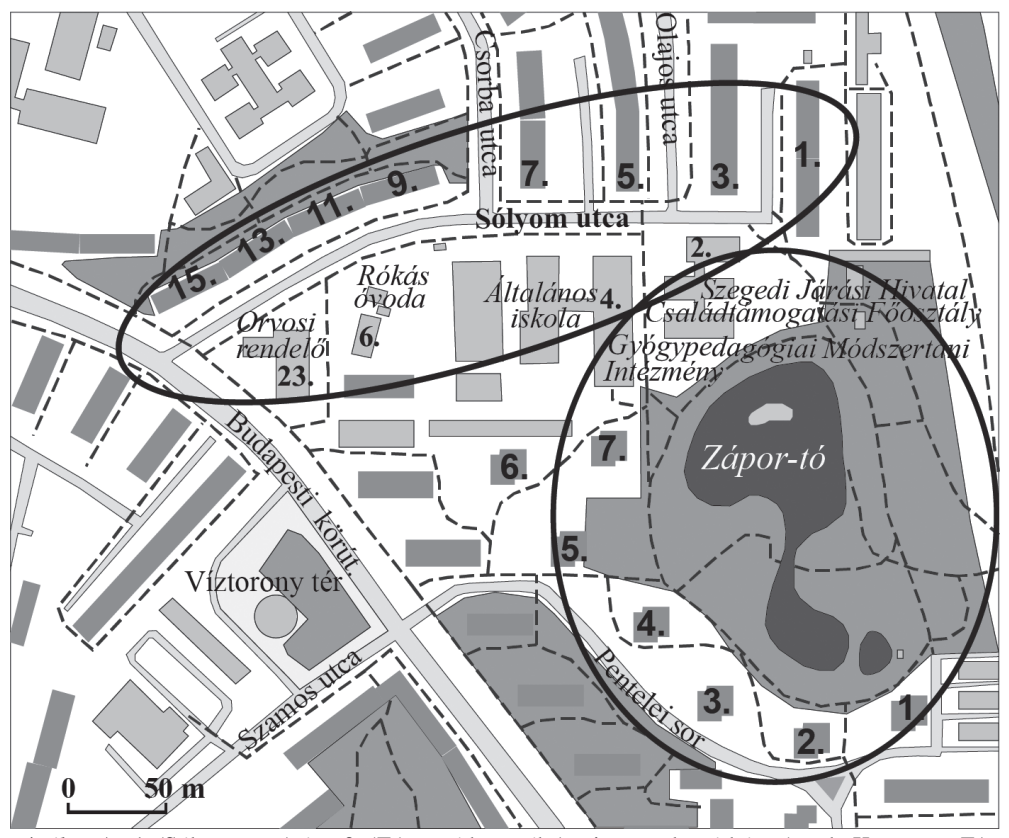

4. ábra Az 1. (Sólyom utca) és a 2. (Zápor-tó környéke) mintaterület térképe (szerk. KARANCSI Z.)

Figure 4 The research area 1 (Sólyom Street) and 2 (Lake Zápor) on map (ed. by KARANCSI, Z.)

2. táblázat-Table 2

A Sólyom utca páratlan oldala épületeinek és környezetének értékelése (szerk. KARANCSI Z.)

Evaluation of the buildings and environment on the odd side of the Sólyom Street (ed. by KARANCSI, Z.)

\begin{tabular}{lcccccccc}
\hline Házszám & $\mathbf{1 5}$ & $\mathbf{1 3}$ & $\mathbf{1 1}$ & $\mathbf{9 .}$ & $\mathbf{7 .}$ & $\mathbf{5 .}$ & $\mathbf{3 .}$ & $\mathbf{1 .}$ \\
\hline Épület állapota & 3 & 3 & 3 & 3 & 3 & 3 & 3 & 3 \\
Nem lakóépület állapota & - & - & - & - & - & - & - & - \\
Dísznövényzet & 2 & 2 & 2 & 2 & 3 & 3 & 3 & 3 \\
\hline Utcabútor, -dísz & 1 & 1 & 1 & 1 & 1 & 1 & 1 & 1 \\
Játszótér, tornapálya & - & - & - & - & - & - & - & 1 \\
Street art & - & - & - & - & - & - & - & - \\
Gyomnövény & - & - & - & - & - & - & - & - \\
Penészes fal & - & - & - & - & - & - & - & -1 \\
Falfirka (grafitti) & -1 & - & - & - & - & - & - & -1 \\
Megrongált pad (utcadísz) & - & - & - & - & - & - & - & - \\
Megrongált játszótéri (tornapálya) eszközök & - & - & - & - & - & - & - & - \\
Piszok (por), szemét & - & - & - & - & - & - & - & - \\
Töredezett járda & -1 & -1 & -1 & -1 & - & - & - & - \\
Reklámhirdetés, reklámtakarás & - & - & - & - & - & - & - & - \\
Forgalom (zaj) & -1 & - & - & - & - & - & - \\
Ö-sszesített érték & 3 & 5 & 5 & 5 & 7 & 7 & 7 & 6 \\
\hline
\end{tabular}


vonások okozzák. Ezért - mint fentebb részben már említettük - úgy véljük, hogy ilyen esetben nem szükséges épületenként elvégezni a vizsgálatot, hanem célszerúbb nagyobb, szemünkkel jól belátható vizuális egységek értékelésével leegyszerúsíteni a feladatot. A vizuális egységek értékelése során a részletek nem minden esetben fedezhetôk fel, de mindenképpen egy esztétikai összbenyomás jelenik meg a pontokban, amit csak a jelentősebb vizuális konfliktusok módosíthatnak. Bár emiatt az összpontszámok tekintetében 1-2 pont különbség mutatkozik a részletes felméréshez képest, mégis úgy véljük, hogy az emberek legnagyobb része ilyen távlatokban észleli környezetét és alakít ki véleményt annak látványáról. Az eredmény pedig a hasonló módszerrel értékelt vizuális egységekkel összehasonlítható.

Az utca páros oldalát vizsgálva megállapítható, hogy ott különböző közösségi épületek (orvosi rendelő, óvoda, iskola, kormányhivatal) vannak parkos környezetben, és a fák (növények) takarásának köszönhetően csak közelről, vagy egyáltalán nem érzékelhetők a részletek, ami a szemnek kellemesebb, ezáltal növeli az esztétikai értéket (3. táblázat, 5. ábra).

3. táblázat - Table 3

A Sólyom utca páros oldala épületeinek és környezetének értékelése (szerk. KARANCSI Z.)

Evaluation of the buildings and environment on the even side of the Sólyom Street (ed. by KARANCSI, Z.)

\begin{tabular}{lcccc}
\hline Házszám & $\begin{array}{c}\text { Budapesti } \\
\text { krt. 23. }\end{array}$ & $\mathbf{6}$ & $\mathbf{4 .}$ & $\mathbf{2}$ \\
\hline Épület állapota & - & - & - & - \\
Nem lakóépület állapota & 3 & 2 & 2 & 3 \\
Dísznövényzet & 3 & 3 & 3 & 1 \\
Utcabútor, -dísz & 1 & 1 & 1 & - \\
Játszótér, tornapálya & - & - & - & - \\
Street art & - & - & - & - \\
Gyomnövény & - & - & - & - \\
Penészes fal & - & - & -1 & - \\
Falfirka (grafitti) & - & - & -1 & - \\
Megrongált pad (utcadísz) & - & - & - & - \\
Megrongált játszótéri (tornapálya) eszközök & - & - & - & - \\
Piszok (por), szemét & - & - & - & - \\
Töredezett járda & - & - & -1 & -1 \\
Reklámhirdetés, reklámtakarás & - & - & - & - \\
Forgalom (zaj) & - & - & - & - \\
Összesített érték & 7 & 6 & 3 & 3 \\
\hline
\end{tabular}

\section{A 2. mintaterület (Zápor-tó és környéke) környezetesztétikai értékelése}

A Sólyom utcát egy gyalogút köti össze a Zápor-tóval és annak környezetével, amely az utóbbi néhány évben mind építészetileg, mind tájépítészetileg megújult a tízemeletes épületek panelprogramjának megvalósulása és a lezajlott parkrehabilitáció következtében, így Szeged egyik legvonzóbb rekreációs területévé vált (4., 6. ábra). A terület attraktivitását növeli a nagyobb testú, védett madarak (pl. nagykócsag) rendszeres feltúnése is. 

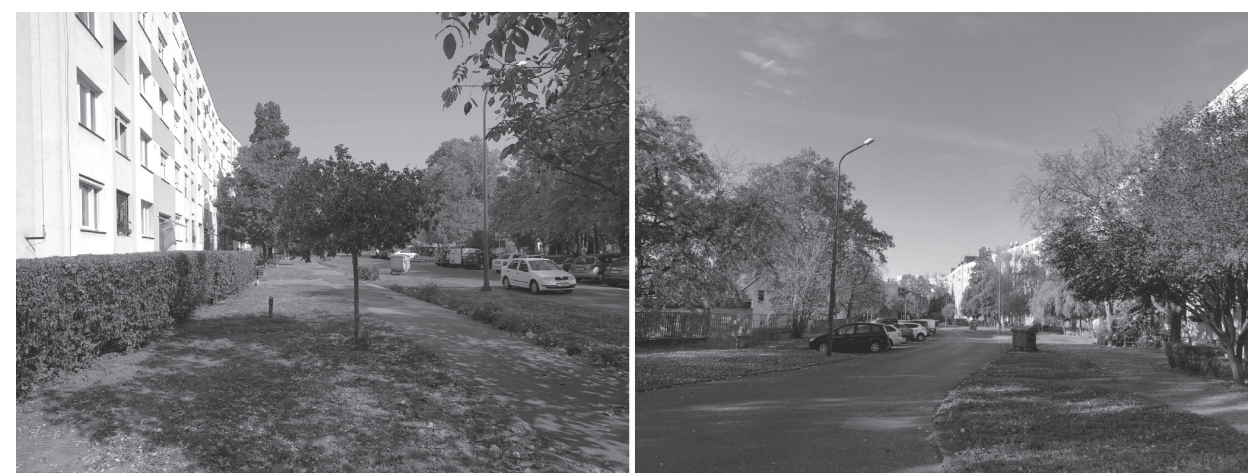

5. $a$-b) ábra A Sólyom utca délről (a) és északról (b) (fotó KARANCSI Z.)

Figure $5 a-b$ ) The Sólyom Street from south (a) and north (b) (photo KARANCSI, Z.)

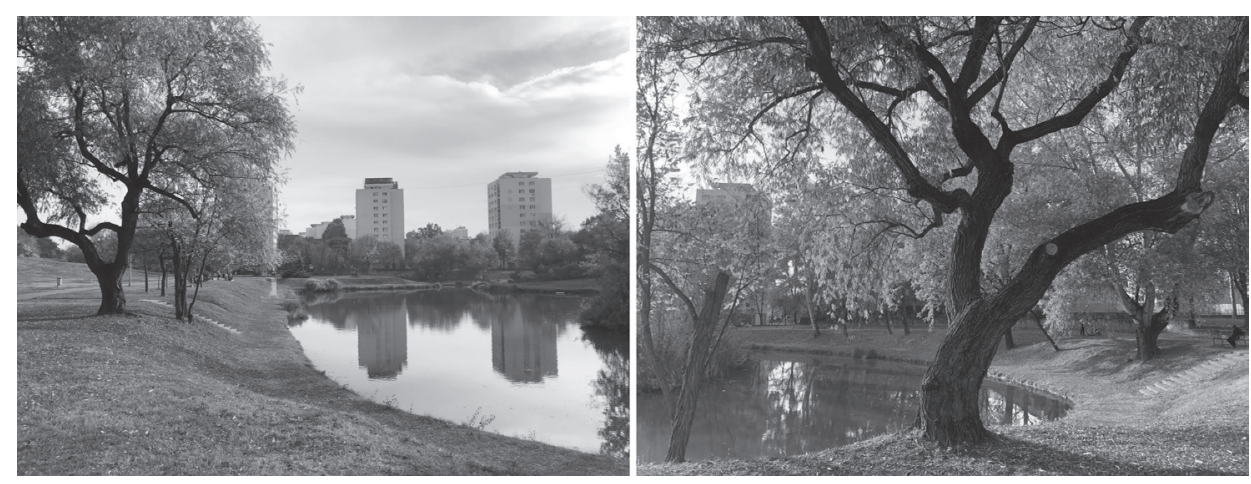

6. $a$-b) ábra A Zápor-tó és felújított környezete (fotó KARANCSI Z.)

Figure $6 a-b$ ) The Zápor Lake and its renovated surrounding area (photo KARANCSI, Z.)

Először itt is a „hagyományos” értékelést végeztük el, vagyis a házakat és közvetlen környezetüket pontoztuk (4.táblázat), ami abból a szempontból nem is volt egyszerû, hogy itt parkosított szabad ,áramló tér” választja el egymástól az önálló toronyházakat, vagyis

\section{A Zápor-tó épületeinek és közvetlen környezetüknek az értékelése}

4. táblázat - Table 4 (szerk. KARANCSI Z.)

Evaluation of the buildings and environment next to the Lake Zápor (ed. by KARANCSI, Z.)

\begin{tabular}{lccccccc}
\hline Házszám & $\mathbf{7 .}$ & $\mathbf{6 .}$ & $\mathbf{5 .}$ & $\mathbf{4 .}$ & $\mathbf{3 .}$ & $\mathbf{2 .}$ & $\mathbf{1 .}$ \\
\hline Épület állapota & 3 & 3 & 3 & 3 & 3 & 3 & 3 \\
Nem lakóépület állapota & 1 & - & - & - & - & - & 1 \\
Dísznövényzet & 3 & 3 & 3 & 3 & 3 & 3 & 3 \\
\hline Vízfelület & 2 & 1 & 2 & 2 & 2 & 2 & 2 \\
Utcabútor, -dísz & 1 & 1 & 1 & 1 & 1 & 1 & 1 \\
Játszótér, tornapálya & 2 & 2 & 2 & 2 & 2 & 2 & 2 \\
Street art & 1 & 1 & 1 & 1 & 1 & 1 & 1
\end{tabular}




\begin{tabular}{lccccccc}
\hline Házszám & $\mathbf{7}$ & $\mathbf{6}$ & $\mathbf{5}$ & $\mathbf{4}$ & $\mathbf{3 .}$ & $\mathbf{2 .}$ & $\mathbf{1}$ \\
\hline Elhanyagolt vízfelület & - & - & - & - & - & - & -1 \\
Gyomnövény & - & - & - & - & - & - & - \\
Penészes fal & - & - & - & - & - & - & - \\
Falfirka (grafitti) & - & - & - & - & - & - & -1 \\
Megrongált pad (utcadísz) & - & - & - & - & - & - & - \\
Megrongált játszótéri (tornapálya) eszközök & - & - & - & - & - & - & - \\
Piszok (por), szemét & - & - & - & - & - & - & - \\
Töredezett járda & - & - & -1 & - & -1 & -1 & -1 \\
Reklámhirdetés, reklámtakarás & - & - & - & - & - & - & - \\
OÓsszesített érték & 13 & 11 & 11 & 12 & 11 & 11 & 10 \\
\hline
\end{tabular}

hiányzik a hagyományos értelemben vett utca. Meglepő módon igen magas pontszámok születtek, amit érdemben a még itt is észlelt vizuális konfliktusokért kapott pontlevonások sem befolyásoltak. A lakótelepeken kialakított virágágyások, kis közösségi kertek (7. ábra), amelyek közösségépító funkciójuk mellett zöldterületként, de akár élelmiszertermelés céljára is használhatók, a városrehabilitáció fontos eszközeinek is tekinthetők (BENDE Cs.-NAGY Gy. 2016).

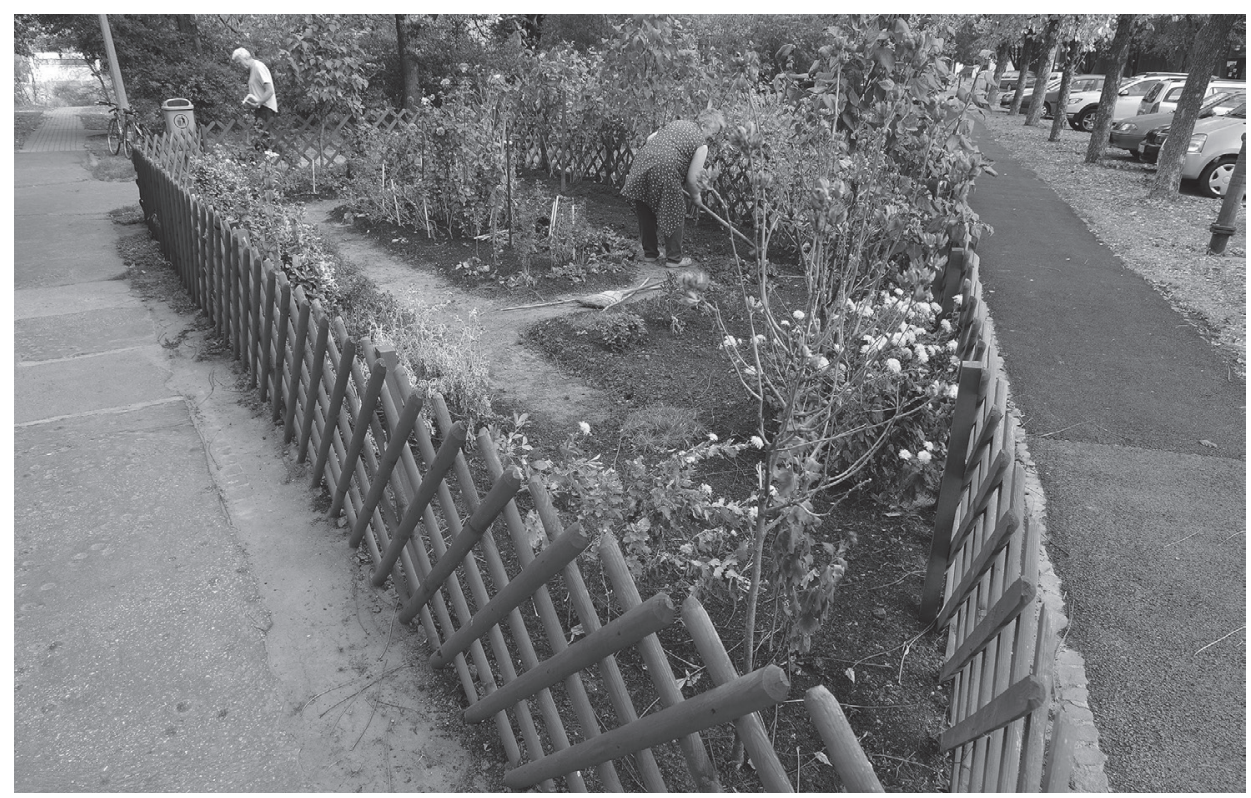

7. ábra Gondozott közösségi kert a Zápor-tónál (fotó KARANCSI Z.)

Figure 7 Well maintained community garden close to the Zápor Lake (photo KARANCSI, Z.)

Ez is azt mutatja, hogy milyen fontos szerepe van a pozitív megítélésben egy jó állapotban lévő, természetközelibb környezetnek, még akkor is, ha nem múvészettörténeti szempontból értékes épületeket, csupán felújított és az újrafestés színeinek variálásával izgalmasabbá változtatott, 10 emeletes panelépületeket vesznek körül. 
A következő feladat a vizuális egységek létrehozása volt. A vizsgált területet három egység fedte le (8.ábra). Az értékelést ezekre a területekre is elvégeztük (5. táblázat).

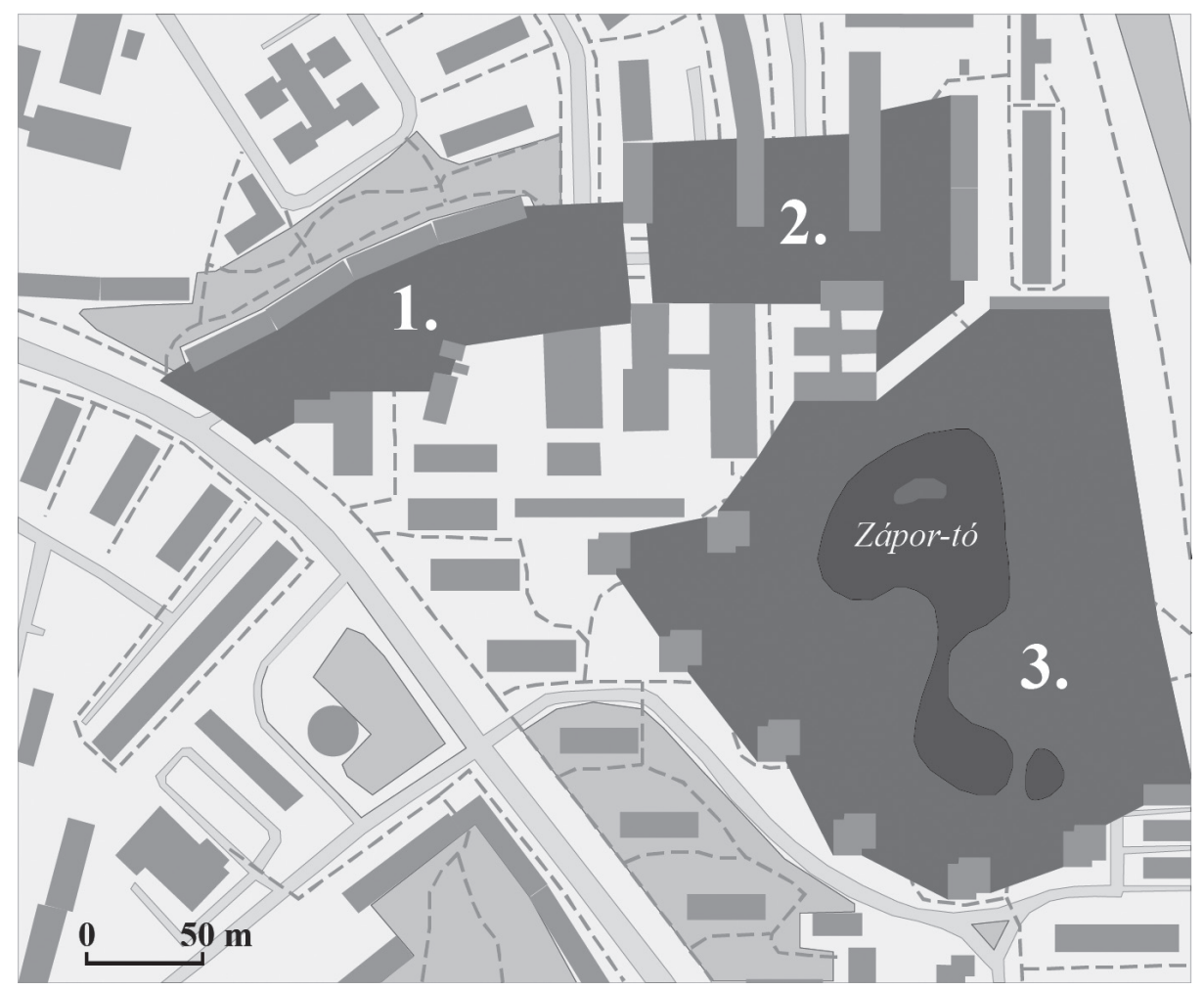

8. ábra Vizuális egységek kialakítása Tarjánban (szerk. KARANCsi Z.)

Jelmagyarázat: 1 - Külső Sólyom utca; 2 - Belső Sólyom utca; 3 - Zápor-tó környéke

Figure 8 Identification of visual blocks in Tarján (ed. by KARANCSI, Z.)

Legend: 1 - Külső (Outer) Sólyom Street; 2 - Belső (Inner) Sólyom Street; 3 - vicinity of Lake Zápor

5. táblázat - Table 5

A tarjáni vizuális egységek értékelése I. (szerk. KARANCSI Z.)

Evaluation of visual blocks in Tarján I. (ed. by KARANCSI, Z.)

\begin{tabular}{lccc}
\hline Vizuális egység & $\begin{array}{c}\text { Külsó } \\
\text { Sólyom utca } \\
(\mathbf{1 . )}\end{array}$ & $\begin{array}{c}\text { Belsólyom } \\
\mathbf{( 2 . )}\end{array}$ & $\begin{array}{c}\text { Zápor-tó } \\
\text { környéke } \\
\mathbf{( 3 . )}\end{array}$ \\
\hline Épület állapota & 3 & 3 & 3 \\
Nem lakóépület állapota & 3 & 2 & 2 \\
Dísznövényzet & 3 & 3 & 3 \\
\hline Vízfelület & - & - & 2 \\
Utcabútor, -dísz & 1 & 1 & 2 \\
Játszótér, tornapálya & - & 1 & 2 \\
Street art & - & - & 1 \\
\hline
\end{tabular}


Vizuális egység

\begin{tabular}{lccc} 
& (1.) & (2.) & (3.) \\
\hline Elhanyagolt vízfelület & - & - & -1 \\
Gyomnövény & - & - & - \\
Penészes fal & - & -1 & - \\
Falfirka (grafitti) & -1 & -1 & -1 \\
Megrongált pad (utcadísz) & - & - & - \\
Megrongált játszótéri (tornapálya) eszközök & - & - & - \\
Piszok (por), szemét & - & - & - \\
Töredezett járda & -1 & -1 & -1 \\
Reklámhirdetés, reklámtakarás & - & - & - \\
Forgalom (zaj) & -1 & - & - \\
Összesített érték & 7 & 7 & 13 \\
\hline
\end{tabular}

Mivel a meghatározás szerint kialakított vizuális egységeket a szemünk által jól befogható (beazonosítható) épületekkel, növényekkel lehatárolt téregységként hoztuk létre, ezért a középen megtörô, nagyjából 350 méter hosszú Sólyom utcát két belátható egységre bontottuk.

A táblázat alapján megállapítható, hogy a Sólyom utcai vizuális egységek majdnem feleannyi pontot kaptak, mint a Zápor-tavi egység (6. táblázat).

A tarjáni vizuális egységek értékelése II. (szerk. KARANCSI Z.)

6. táblázat - Table 6

Evaluation of the visual blocks in Tarján II. (ed. by KARANCSI, Z.)

\begin{tabular}{lccc}
\hline Vizuális egység & $\mathbf{1}$ & $\mathbf{2}$ & $\mathbf{3}$ \\
\hline Vizuális egységben értékelt épületek száma & 6 & 6 & 6 \\
VÉI & 5,0 & 5,5 & 11,2 \\
\hline
\end{tabular}

Az első kettônél a jelentősebb eltérést a nagyobb számú vizuális konfliktus miatti pontlevonás okozta, amit a legtöbb épületnél alkalmazni kellett. (Ezzel szemben az egységes vizsgálatkor a látható konfliktusokért csak egyszer történik pontlevonás.)

Ha ezeket az értékeket három kategóriába sorolva térképre vetítjük, akkor kirajzolódnak az esztétikai szempontból értékes, a javításra szoruló, kisebb intézkedéseket kívánó, illetve a jelentősebb beavatkozást igénylő területek. Mivel a vizsgált vizuális egységek közül egyik sem került a legrosszabb, 3 -as (esztétikailag problémás, taszító) kategóriába, ezért a jelmagyarázatba is csak a térképen ábrázolt két kategória került.

\section{A 3. mintaterület (Rókusi körút és a Vér-tó környéke) környezetesztétikai értékelése}

Harmadik vizsgálati területnek a forgalmas Rókusi körút két oldalán a Vér-tóig húzódó panelházas övezetet választottuk Újrókuson (9. ábra). 


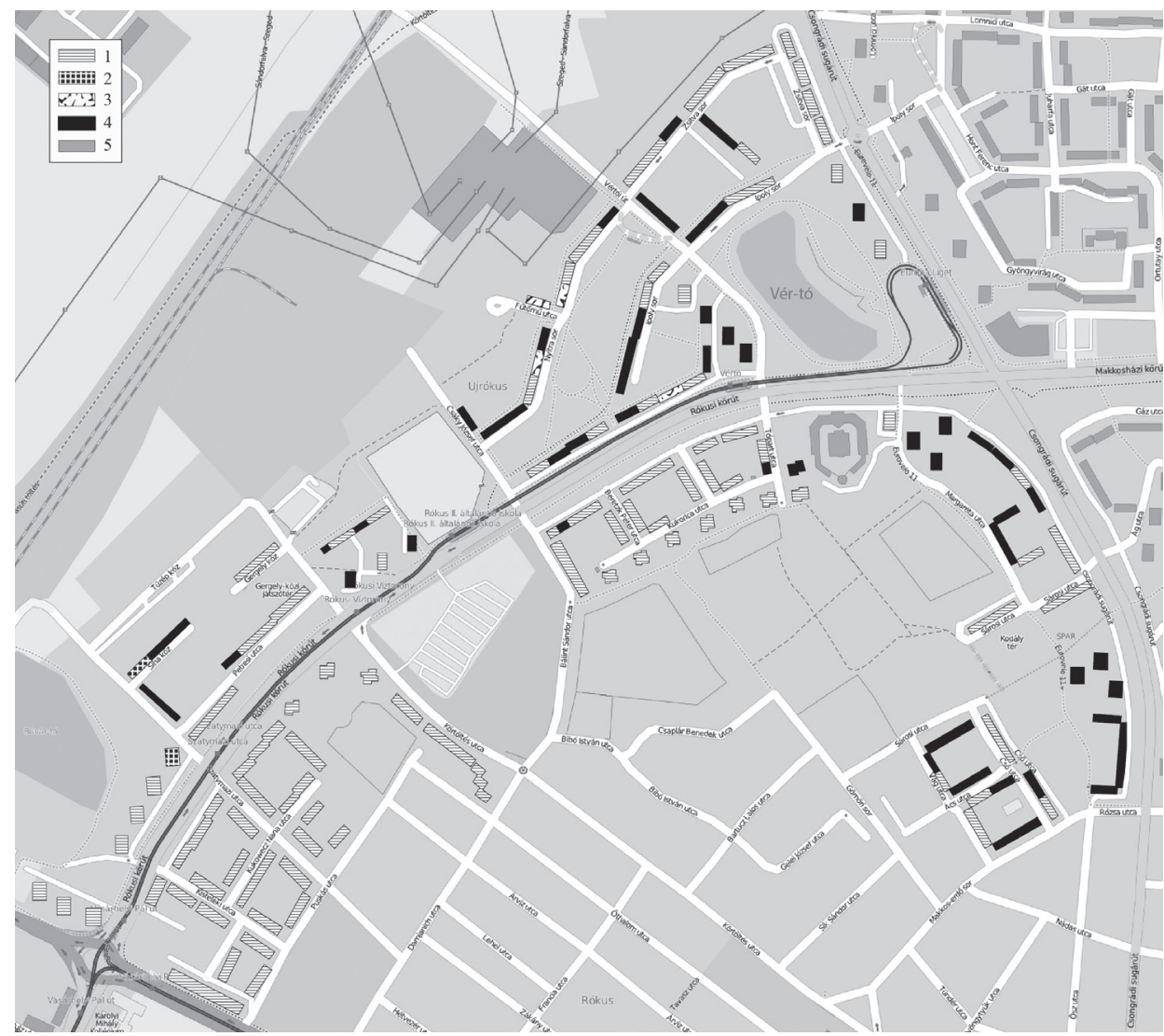

9. ábra Újrókusi panelek (lakóépületek) felújításának foka (szerk. HORNYÁK S.)

Jelmagyarázat: 1 - homlokzati felújítás nélküli épület; 2 - részleges felújításon (nyílászárócsere) átesett épület; 3 - részleges felújításon (hőszigetelés, festés) átesett épület;

4 - komplex felújításon (nyílászárócsere, hőszigetelés, festés) átesett épület; 5 - a vizsgált területen kívüli panelépület

Figure 9 The grade of renovation of buildings (housing estate) in Újrókus, Szeged, Hungary (ed. by HoRNYÁK, S.)

Legend: 1 - building without renovation of facade; 2 - building with partial renovation (insulation, colouring); 3 - building

with complex renovation (windows, insulation, colouring); 4 - housing estate buildings outside the investigated area

Itt a jóval nagyobb terület miatt eleve vizuális egységekben gondolkodtunk. Jól láthatóan a Rókusi körút környékén a legnagyobb a változatosság a panelrekonstrukció terén (10. ábra). A szigetelés nélküli házak jelentős száma annak köszönhető, hogy ezek voltak Szeged utoljára, az 1980-as években felépített panelházai, és az épületek fiatal kora, valamint a korszerúbb építési technológia következtében ezek a házak még nem igénylik a szigetelést. Az évtizedek pora, korma azonban már nyomot hagyott a falakon; ez a további kisebb hiányosságokkal (repedezettség, festékhiány, rozsdás csövek, gondozatlan növények) együtt növeli a kapott hibapontokat. Ennek pontosan ellentéte a Vér-tó környéke. Az egykor gyúlölt, elhanyagolt tóparti emeletes házak a panelfelújítás és a tó-, valamint parkrehabilitáció után Szeged lakótelepei közül az egyik legvonzóbb hellyé váltak (11. ábra).

A vizsgált terület tengelyében húzódik a Rókusi körút, amelyen nagyszámú személyautó és számos tömegközlekedési eszköz mozog a nap legnagyobb részében. Ezen eszközök használatához kapcsolódóan légvezetékek jelentős mennyiségú „kötege” csúfítja 


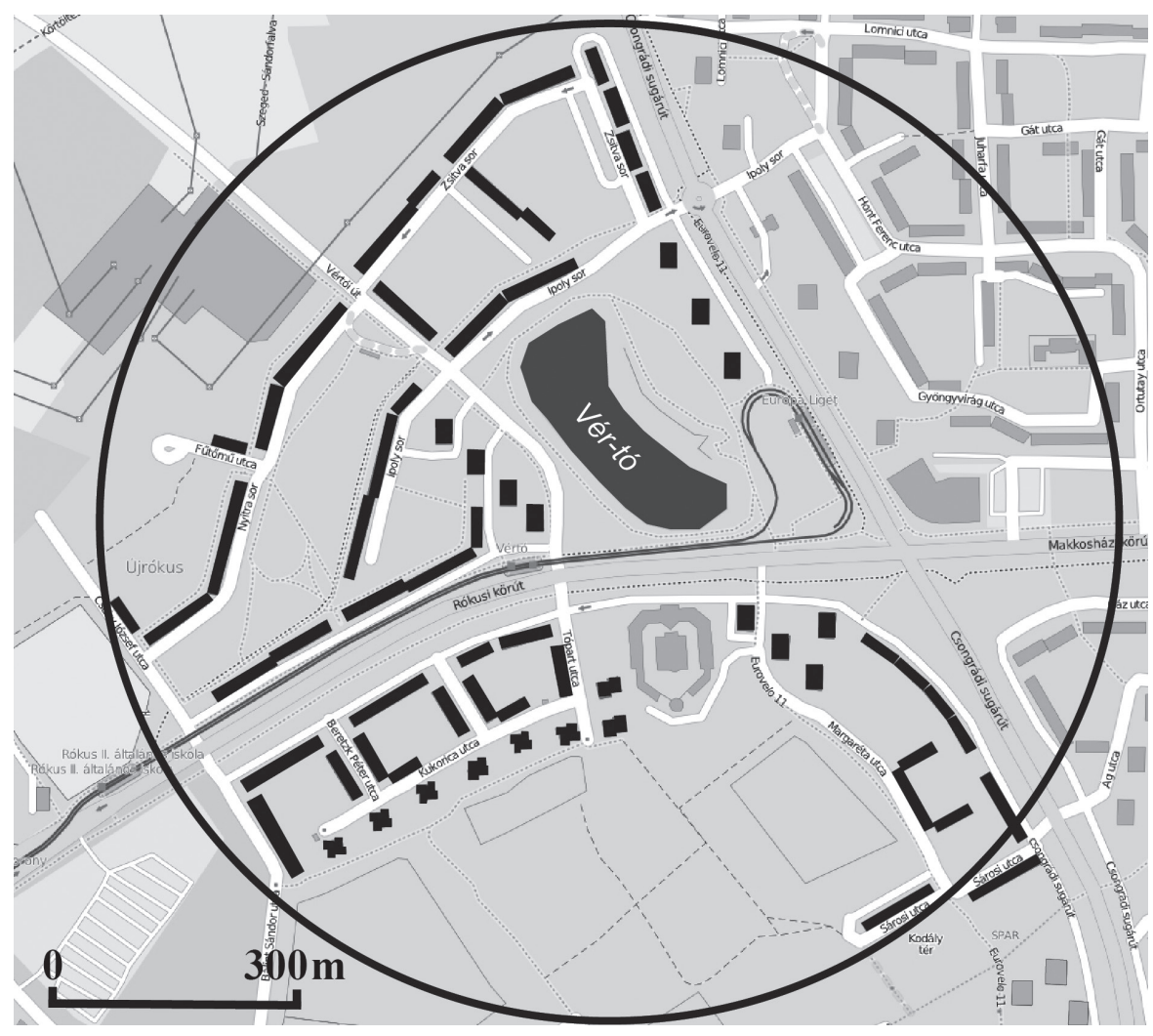

10. ábra A 3. mintaterület (Rókusi körút és Vér-tó környéke) (szerk. HoRnYÁK S.-KARANCsI Z.) Figure 10 The research area 3 (Rókus Blvd and Vér Lake) (by HornYák, S.-KaranCsi, Z.)

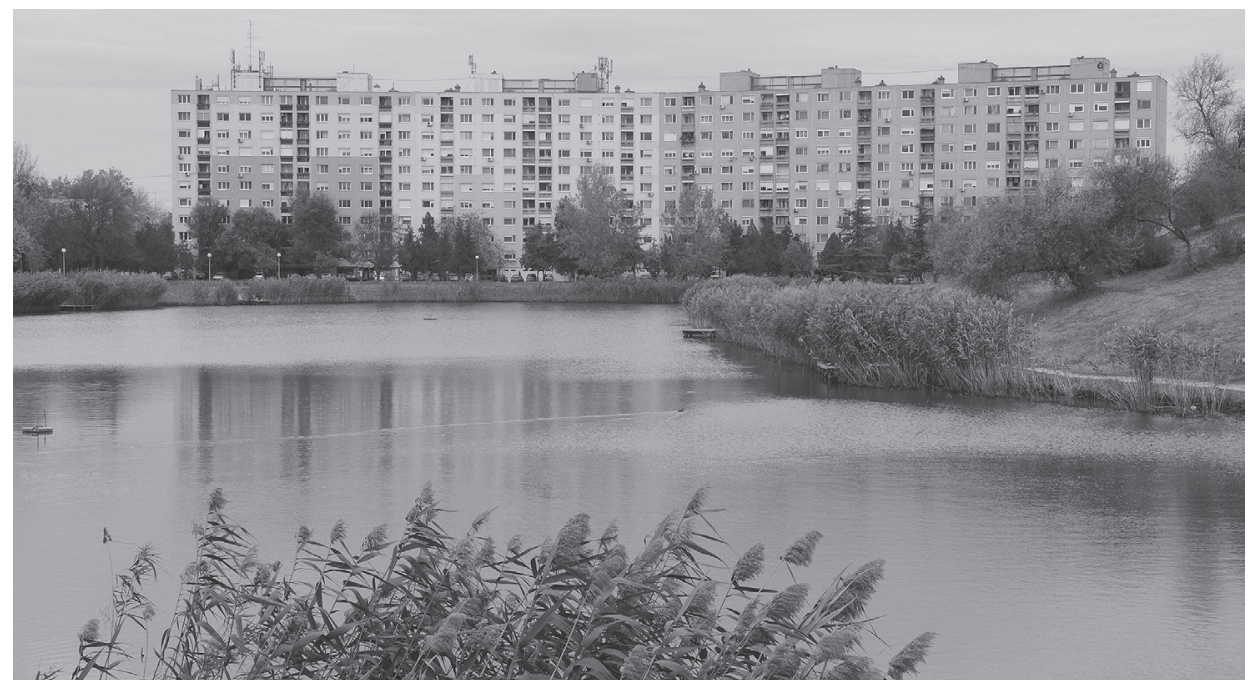

11. ábra A Vér-tó rekonstrukción átesett környéke (fotó KARANCSI Z.)

Figure 11 The renewed area of the Vér Lake (photo KARANCSI, Z.) 
a városképet (3.b.ábra). A vizuális egységek (12.ábra) lehatárolása legtöbbször könnyen ment, hiszen pl. a sorházak vagy egy facsoport, amik gátat jelentenek a kilátásnak, egyben a területhatárt is meghatározzák. Ugyanakkor voltak problémás területek is. A Rókusi körút jelentős forgalma jelentős mennyiségű port, piszkot, forgalmi zajt, bűzt stb. eredményez. A legnagyobb kihívást éppen ezért a 16. egység kijelölése adta, mivel ott nincs épület vagy fasor, ami határt szabna az észlelésnek. A másik probléma abból adódik, hogy az útról belátni mindkét irányba. De mivel a Rókusi körút szakaszai a mintaterület legnagyobb terhelésű helyévé váltak, a korábban kijelölt, jól lehatárolható 1. vizuális egység folytatásaként, magára az útra korlátozva alakítottuk ki a 16. egységet is (7. táblázat).

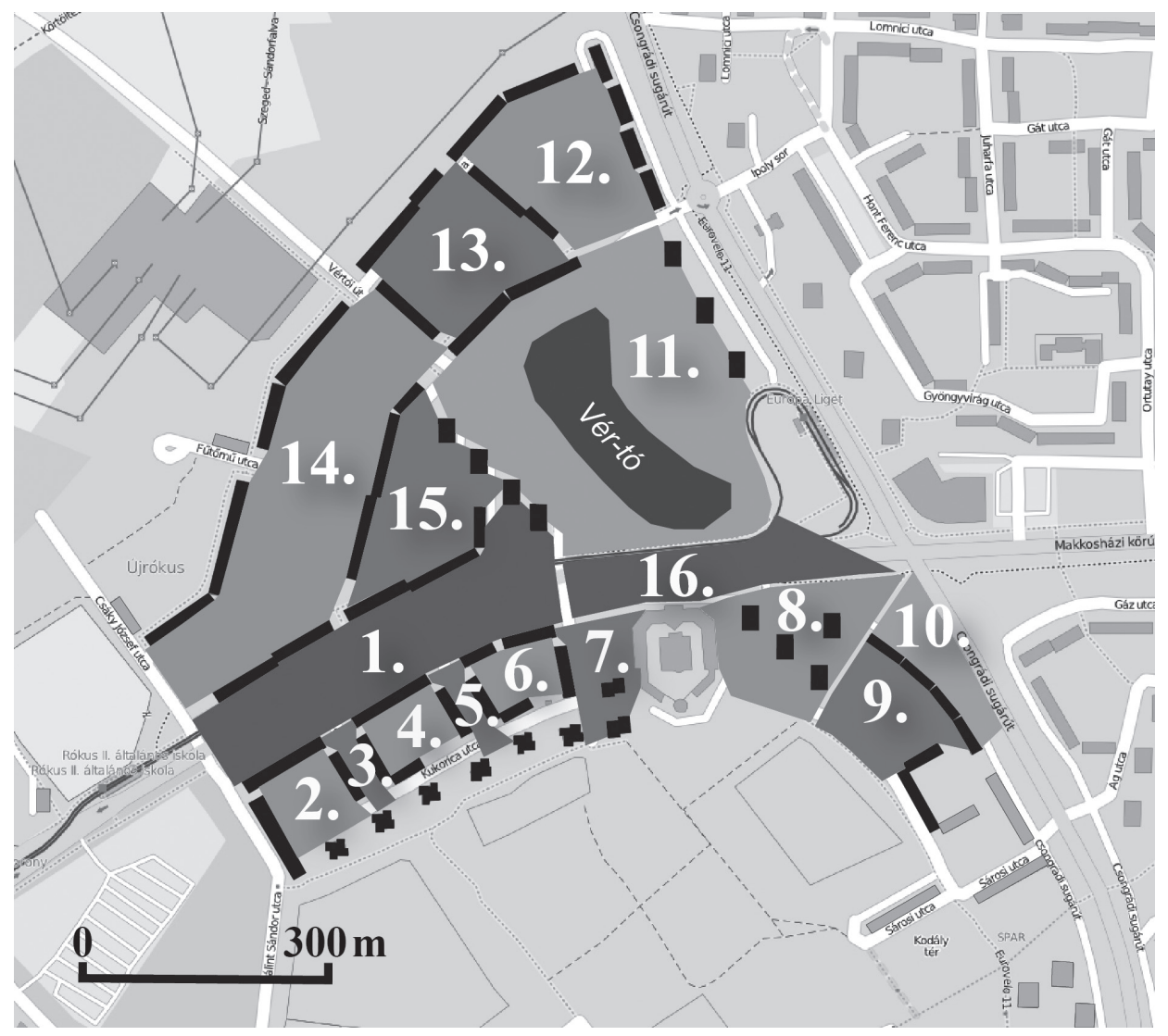

12. ábra A Vér-tó menti mintaterület vizuális egységei (szerk. KARANCSI Z.) Figure 12 Visual blocks of the Vér Lake research area (ed. by KARANCSI, Z.)

A 7. táblázatból leolvasható, hogy a kapott értékek széles skálán mozognak. A legkevesebb pontot a legnagyobb terhelésnek kitett körúti szakaszok kapták, a legmagasabb pontszámot pedig a Vér-tó környéke. A körút déli oldalán a 2. vizuális egységtől haladva a 8. felé növekedést figyelhetünk meg, ami azzal magyarázható, hogy a 2. egység mellett található Tesco nagyáruházhoz közeli területek elhanyagoltabbak (összefirkált falak, töredezett járda), mint attól távolodva. A forgalmas körút túloldalán szintén a Vér-tó felé haladva egyre kulturáltabb, ezáltal értékesebb területekkel találkozunk. A Vér-tó környéke 


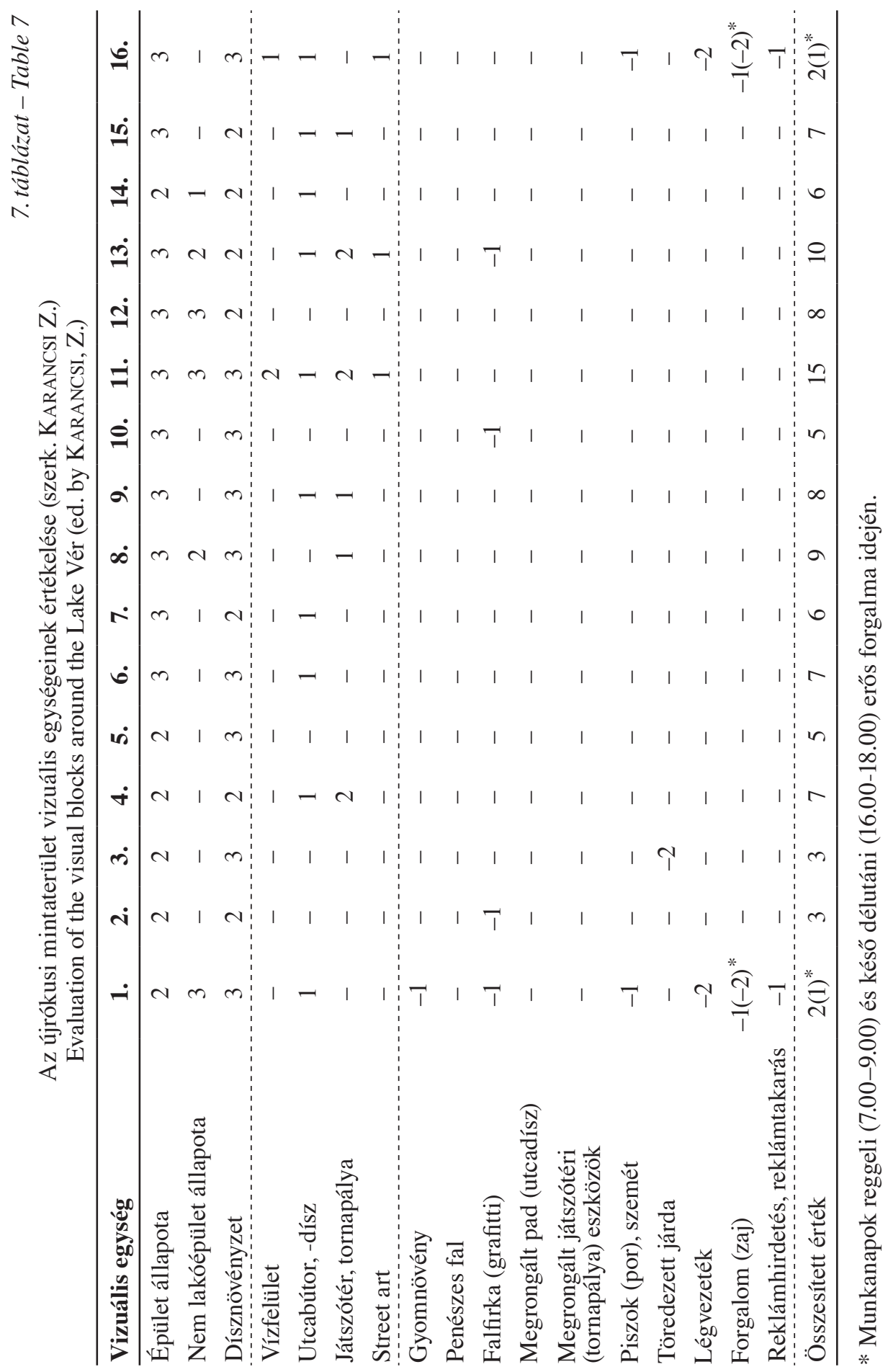


kapta a maximális 15 pontot, ami jól mutatja, hogy a lakótelepeknek szüksége van egy kulturált, többfunkciós rekreációs területre, ami az ott végezhető különböző szabadidős tevékenységek mellett a látványának köszönhetően a szem (és a lélek) számára is élményt nyújt (13. ábra). Nem véletlen, hogy a városfejlesztés különös súlyt fektet a különböző városrészekben található tavak revitalizációjára, azok környezetének rehabilitációjára (1. Tarján városrész felújítása, https://www.szegedvaros.hu/beruhazasok5/).

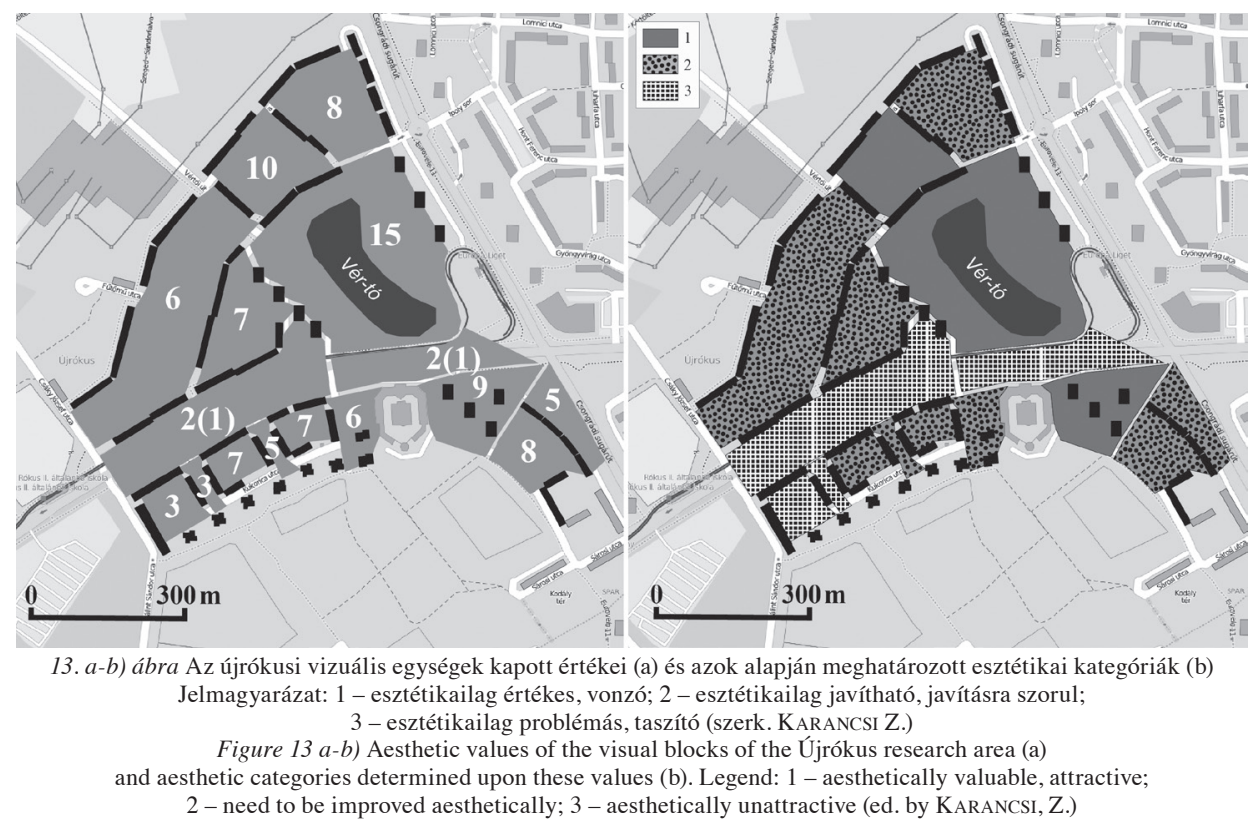

Végül még megjegyzendő, hogy nyomon követhető a szegedi lakótelepi lakosság szemléletváltozása is. Egyre jellemzőbbek a területet „lelkileg is birtokba venni akaró” magatartásformák, kezdeményezések. A lakótelepek színfoltjai a helyi lakosok által kezdeményezett és múvelt kertek, amelyekben a helyiek olykor kifejezetten drágának számító különleges, távoli tájakon honos növények (díszbanán, ciprus, füge, datolya) életben tartásával kísérleteznek. Általános, hogy a korábban rongálásként indult falfestés is megszelídülni látszik, szinte díszítő értékú naiv múvészetté (street art) alakul át.

\section{Következtetések és összefoglalás}

A szegedi lakótelepek esztétikai állapota az 1990-es évek múszaki avulása és társadalmi megingása által kiváltott mélypont után a 2000-es években javulásnak indult. A városvezetők, vállalkozók és a lakosság hozzáláttak a lakókörnyezet rehabilitációjához és jelentős tömegközlekedési modernizációt is végrehajtottak. Nagyfokú javulást eredményezett a településképben a lakóépületek karakterének megváltoztatása, illetve a települési szolgáltató központok rendezése, azok küllemének javítása.

EGEDY T. (2005) tanulmánya nyomán vetődött fel annak igénye, hogy megvizsgáljuk Szeged város lakótelepeinek jövőképességét településkép szempontjából. A területenként ugyan eltérô mértékú, de egészében véve mégis javulást eredményező rehabilitációs folya- 
matok hatására a szegedi lakótelepeken nincs olyan létesítmény, amely az EGEDY által említett „nem menthető” kategóriába tartozna. A korszak társadalmi válságtünetei nem a lakótelepeken, hanem más településtípusok (aprófalvak, korábbi munkástelepek) esetében mélyültek el igazán. Meg kell jegyeznünk ugyanakkor, hogy a lakótelepek a lakáspiacon betöltött súlyuknál és szerepüknél fogva kockázatot jelentenek a városok számára. Az elmúlt két évtizedben a lakótelepek érdekében tett erófeszítések a problémák veszélyessé válását csupán késleltetni tudják, azok a felújítások műszaki avulásával újból és a korábbival összemérhető nagyságrendben jelentkeznek majd.

Megítélésünk szerint a tanulmányban tárgyalt módszer alkalmas a kevéssé változatos, homogén építészeti környezet és az azt körülvevő területek környezetesztétikai minősítésére. Lakótelepek esztétikai vizsgálatánál általában elégséges a kisebb ráfordítást igénylő vizuális egységeket értékelni, de ahol szükség van a részletekre, ott lehetőség van a minősítés finomítására is. Kutatásunk fontos eredménye a három kategóriát felvonultató tematikus térképi megjelenítés, ahol jól elkülöníthető az esztétikailag értékes, ezért vonzó, az esztétikai szempontból problémás, ezért taszító, a kettő között pedig a kisebb beavatkozással javítható (sőt javítandó) esztétikai kategória is.

\section{Köszönetnyilvánítás}

A tanulmány a JGYPK támogatásával készült (Cs-007/2017).

KARANCSI ZOLTÁN

SZTE JGYPK Földrajzi és Ökoturisztikai Tanszék, Szeged

zkarancsi@gmail.com

HORNYÁK SÁNDOR

ATIVIZIG, Szeged

hornyaks@jgypk.szte.hu

SZALMA ElEMÉr

SZTE JGYPK Földrajzi és Ökoturisztikai Tanszék, Szeged szalma@jgypk.szte.hu

KOROM ANNAMÁRIA

SZTE JGYPK Földrajzi és Ökoturisztikai Tanszék, Szeged korom.annamaria@jgypk.szte.hu

OlÁH FerEnC

SZTE JGYPK Földrajzi és Ökoturisztikai Tanszék, Szeged oreg@jgypk.u-szeged.hu

HORVÁTH GERGELY

ELTE TTK Földrajz- és Földtudományi Intézet, Környezet- és Tájföldrajzi Tanszék, Budapest horvger@caesar.elte.hu

\section{IRODALOM}

BEnde Cs.-NAGY Gy. 2016: Közösségi kertek Szegeden. - Empirikus vizsgálatok és esettanulmányok. Földrajzi Közlemények 140. 1. pp. 55-72. 
BENKő, M. 2012: Evaluating Factors in the Image of Housing Estates. - Periodica Polytechnica Architecture 43. 1. pp. 33-36.

BENKő M.-BALla R. 2016: Fundamentum - A paneles lakóépületek földszintje. - Építés - Építészettudomány 44. 3-4. pp. 317-332.

Blazovich L. 2007: Szeged rövid története. - Dél-Alföldi évszázadok 21. Szeged. 319 p.

BudAi A. 2004: Környezetesztétika, elmélet és gyakorlat. - Építésügyi Tájékoztatási Központ Kft. Budapest. $120 \mathrm{p}$.

Coleman, A. M. 1985: Utopia on trial: vision and reality in planned housing. - Hilary Shipman Ltd. 219 p.

DEKKER, K. 2011: Residential satisfaction in housing estates in European cities: a multi-level research approach. - Housing Studies 26. 7. pp. 479-499.

GYÖRGY P.-IFJ. DuRKó Zs. 1993: Utánzatok városa - Budapest. - Cserépfalvi Kiadó, Budapest. 184 p.

EGEDY T. 2000: A magyar lakótelepek helyzetének értékelése. - Földrajzi Értesítő 49. 3-4. pp. 265-283.

EGEDY T. 2005: A lakótelep-rehabilitáció helyzete hazánkban. - In: EGEDY T. (szerk.): Városrehabilitáció és társadalom. Földrajztudományi Kutatóintézet, Budapest. pp. 229-242.

IvÁN L. 1996: Budapesti falanszterek. A tömeges lakásépítés térbeli konzekvenciái. - Földrajzi Értesítő 45. 1-2. pp 73-99.

JACOBS, J. 1961: The death and life of great American cities. - Pimlico. 480 p.

JózSEF D. 1986: Az épített környezet esztétikai értékei (az információesztétika építészeti alkalmazása). - Építés - Építészettudomány 18. 1-2.pp. 427-451.

KARANCSI Z.-HORNYÁK S.-HoRvÁTH G. 2012: Vizuális konfliktusok térképezése egy nagyvárosban. - In: GYŐRI F. (szerk.): A tudás szolgálatában: földrajzi tanulmányok Pál Ágnes tiszteletére. Egyesület KözépEurópa Kutatására, Szeged. pp. 299-312.

KARANCSI Z.-HORNYÁK S.-HoRVÁTH G. 2013: Az első benyomás, avagy városképelemzés egy nagyváros peremén. - In: FRISNYÁK S.-GÁL A. (szerk.): Kárpát-medence: természet, társadalom, gazdaság. Nyíregyházi Főiskola Turizmus és Földrajztudományi Intézet - Bocskai István Gimnázium, Nyíregyháza-Szerencs. pp. 305-318.

Karancsi Z.-Hornyák S.-Korom A.-Szalma E.-OláH F.-Horváth G. 2017: Környezetesztétikai értékelés egy nagyvárosban. - In: BlanKA V.-LADÁNYI Zs. (szerk.) Interdiszciplináris tájkutatás a XXI. században. SZTE Földrajzi és Földtudományi Intézet, Szeged. pp. 305-318.

KONRÁD GY.-SZELÉNYI I. 1969: Az új lakótelepek szociológiai problémái.- Akadémiai kiadó, Budapest. 212 p.

KovÁcs Z.-Douglas, M. 1996: A városépítés időzített bombája - avagy a magyar lakótelep-szindróma társadalomföldrajzi megközelítésben. - Földrajzi Értesítő 45. 1-2. pp. 101-117.

KSH 2013: A 2011. évi népszámlálás. 6. Lakások és lakóik. - Központi Statisztikai Hivatal, Budapest.

Newman, O. 1972: Defensible space; crime prevention through urban design. - Macmillan. 264 p.

PAP Á. (szerk.) 2017: Szeged. Településképi arculati kézikönyv. - Szeged. 224 p. https://www.szegedvaros.hu/letoltheto-csatolmany?ID=28979\&as_attachment=1; Letöltve: 2019. november 15.

Preisich G. (szerk.) 1984: A városépítésről. - Kossuth Könyvkiadó, Budapest. 541 p.

RAINWATER, L. 1970: Behind ghetto walls; black families in a federal slum. - Aldine Transaction. 596 p.

RAMroth, W. 2007: Planning for disaster: how natural and manmade disasters shape the built environment. - Kaplan Business. 304 p.

RÁCZ J.-HOYER M. 1995: Fiatalkori devianciák és kortárs csoportok. Etnográfiai vizsgálat a Jereván-lakótelepen. - Esély 6. 3. pp. 44-55.

SARgisian, T. 2013: Residential environmental conditions on housing estates in Yerevan. - Hungarian Geographical Bulletin 62. 1. pp. 121-130.

Szabó B.-Bene M. 2019: Budapesti lakótelepek a panelprogram előtt és után. - Területi Statisztika 59. 5. pp. $526-554$.

TóTH K.-KESERŰ I. 2001: A lakótelepi panellakások árainak területi különbségei Szegeden. - In: Magyar Földrajzi Konferencia, Szeged. CD-ROM. 10 p.

http://geography.hu/mfk2001/cikkek/TothKKeseru.pdf (letöltve: 2018. szeptember 20.)

VON DER HAGEN-DEMSZKY A. 2005: Helyi társadalom egy budapesti lakótelepen. - BUKSZ 17. 4. pp. 351-356. 